\title{
The Collision Between Federal AND Provincial OCCUPATIONAL HEALTH AND SAFETY REGIMES ON ENERGY AND RESOURCE PROJECTS
}

\author{
LARRY DUNN, ${ }^{*}$ SHAUN HOHMAN** \\ AND E. JANE SIDNELL ${ }^{* * *}$
}

Both federal and provincial occupational health and safety regimes exist in Canada. While these types of laws have similar purposes, there are differences in the standards applied and the consequences imposed. For those projects where both regimes may apply, hidden pitfalls may exist. This article examines the collision of these types of regimes and the constitutional issues that such collisions create, and attempts to clearly delineate under which circumstances each regime will apply.
Le Canada compte un régime de santé et sécurité au travail fédéral ainsi que des régimes provinciaux. Bien que ces lois aient des raisons d'être semblables, il y a des différences sur le plan des normes en vigueur et des conséquences imposées. Dans le cas des projets où les deux régimes pourraient s'appliquer, il peut y avoir des pièges cachés. Cet article examine la collision de ces types de régimes et les questions constitutionnelles que ces collisions créent. Enfin, l'auteur essaie de clairement délimiter les circonstances dans lesquelles chaque régime s'applique.

\section{TABLE OF CONTENTS}

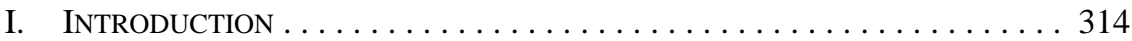

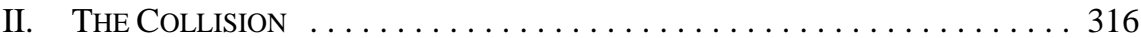

A. CANADA LABOUR CODE ....................... 316

B. Alberta OCCUPATIONAL HeALTH AND SAFETy LEGISLATION $\ldots 316$

C. COlLision BetweEn the CANADA LABOUR CODE AND THE ALBERTA OCCUPATIONAL HEALTH

AND SAFETY LEGISLATION $\ldots \ldots \ldots \ldots \ldots \ldots \ldots \ldots$

III. Constitutional BACKGROUND $\ldots \ldots \ldots \ldots \ldots \ldots \ldots \ldots \ldots \ldots \ldots \ldots$

IV. THE TESTS TO Determine Federal or PROVINCIAL JuRISDICTION . . . . . . . . . . . . . . . . . . 322

A. What Constitutes a Single Federal

WORK OR UNDERTAKING? . . . . . . . . . . . . . . . 322

B. Is THE WORK “INTEGRAL” TO THE FEDERAL UndERTAKING? . . . . 325

V. THE Pith AND SUBSTANCE OF

Occupational Health ANd SAFETy LEgislation . . . . . . . . . . . 328

VI. Determining Which Regime ApPLiEs to Contractors . . . . . . . 330

A. Contractors Are not All Provincially Regulated . . . . . . 330

B. THE PROVINCIAL CONTRACTOR WORKING

on A Federally-REgUlated PRoJect $\ldots \ldots \ldots \ldots \ldots \ldots \ldots 331$

C. WHEN is A ContRactor FEDERALLy REgULATED? . . . . . . . . 332

VII. DECLARATORY RELIEF AS A SOLUTION

to a Constitutional Problem . . . . . . . . . . . . . . . . 334

VIII. Which LegisLative Regime ApPLies? $\ldots \ldots \ldots \ldots \ldots \ldots \ldots \ldots$ 


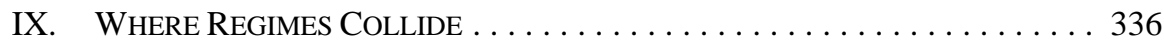

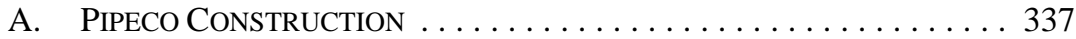

B. INCIDENT REPORTING $\ldots \ldots \ldots \ldots \ldots \ldots \ldots$. . . . . . . . . 338

C. The Practical SolUtion $\ldots \ldots \ldots \ldots \ldots \ldots \ldots \ldots \ldots \ldots \ldots \ldots$

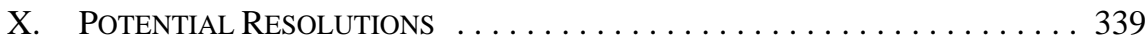

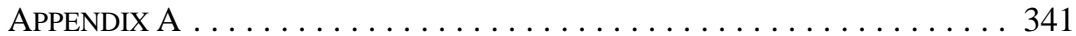

\section{INTRODUCTION}

The duality of federal and provincial laws relating to safety causes concern because, while they have similar purposes, there are differences in the standards applied and the consequences for contraventions of the various pieces of legislation.

Federal and provincial occupational health and safety regimes, in some respects, are radically different. Aside from the differences in the technical requirements and standards, there are differences in the duties they impose, the enforcement provisions, and the penalties. For those projects where both regimes may apply, this dual regime scenario can create hidden pitfalls.

The law is clear that occupational health and safety is a matter that deals with working conditions. As a result, provincial legislation cannot apply to federal undertakings and federal legislation does not apply to provincial works (except in the case of the Criminal Code ${ }^{1}$ ).

There is no bright line determination as to whether provincial or federal occupational health and safety laws, or both of them, apply to a particular project. An owner's analysis follows this path:

(1) Is the owner federally or provincially regulated?

- What makes an entity provincially or federally regulated? The answer is not always obvious.

- Does this business constitute a federal “work” or “undertaking”? The answer requires an analysis of sections 91 and 92 of the Constitution Act, $1867 .^{2}$

(2) Is the project regulated by a level of government because of the inherent nature of the project? If so, what legislation applies to:

- a local project contained wholly within a province, but undertaken by a federally-regulated owner; or

- a federally-regulated work or undertaking being undertaken by a provinciallyregulated owner that may be ancillary to that owner's core business? Is the 
project integral to the owner or is it possible that the project could be independently regulated?

(3) Once the status of the owner is known, the status of the contractors must be examined to determine whether one regime applies or two regimes apply concurrently to the different entities working on the project.

From a practical perspective, owners must ask themselves how they will deal with contractors on their projects who are regulated under a different occupational health and safety regime.

In some scenarios, determining the applicable occupational health and safety regime that applies to owners is relatively straight forward:

(1) provincial legislation, such as the Alberta Occupational Health and Safety Act, ${ }^{3}$ will govern over provincially-regulated entities undertaking provincially-regulated projects, such as:

- $\quad$ operating natural gas wells; oil and gas batteries, plants, and other facilities; producing coal mines; commercial oil sands plants and pipelines regulated by the Alberta Energy Regulator; ${ }^{4}$ or

- $\quad$ investor-owned electric, gas and water utilities, and those municipally-owned electric utilities regulated by the Alberta Utilities Commission; and

(2) federal legislation, the Canada Labour Code, ${ }^{5}$ governs over federally-regulated entities undertaking federally-regulated projects, such as:

- $\quad$ interprovincial or international oil and gas pipelines and additions to existing pipeline systems;

- $\quad$ international power lines and designated interprovincial lines under federal jurisdiction; and

- frontier lands and offshore areas not covered by provincial/federal management agreements.

However, complexity is added where a project is regulated in a different manner than the owner's other undertakings. Furthermore, where provincially-regulated contractors work on projects being undertaken by federally-regulated owners, or federally-regulated contractors for the existing regulatory functions of the ERCB and will attempt to create a more simplified approach for obtaining energy project authorizations (Responsible Energy Development Act, SA 2012, c R-17.3). 
work on projects being pursued by provincially-regulated owners, both federal and provincial legislation may apply to different parties working on a single project.

\section{THE COLLiSiON}

\section{A. CANADA LABOUR CODE}

On federally-regulated projects, the CLC and Canada Occupational Health and Safety Regulations $^{6}$ apply. The CLC governs safety and specifically applies "in respect of employment ... on or in connection with the operation of any federal work, undertaking or business other than a work, undertaking or business of a local or private nature in Yukon, the Northwest Territories or Nunavut."7

\section{B. Alberta OcCupational HeALTH AND SAFETy Legislation}

In Alberta, the governing legislation consists of the OH\&S Act, the Occupational Health and Safety Regulation, ${ }^{8}$ and the Occupational Health and Safety Code $2009^{9}$ (collectively referred to as the Alberta $O H \& S$ Legislation).

\section{COLLISION BETWEEN THE CANADA LABOUR CODE AND THE Alberta OcCupational Health AND SAFETy Legislation}

Many of the requirements of the Canada Labour Code and the Alberta OH\&S Legislation differ. Specifically, there are numerous differences relating to:

- $\quad$ duties, such as the role of the prime contractor;

- $\quad$ reporting of incidents;

- $\quad$ evidentiary value of investigative reports; and

- $\quad$ enforcement and penalties.

Some of the most significant discrepancies between the Canada Labour Code and the Alberta OH\&S Legislation are outlined in the following chart: ${ }^{10}$

\footnotetext{
SOR/86-304 [Canada Regulations].

CLC, supra note 5, s 123(1)(a).

Alta Reg 62/2003.

Alta Reg 87/2009 [OH\&S Code].

This chart is not a comprehensive list of all of the differences between the federal and Alberta requirements for occupational health and safety. In addition to the general differences described in the chart, there are numerous technical differences between the requirements in the federal jurisdiction and Alberta pertaining to health and safety. For example, pursuant to section 16.9 of the Canada Regulations, supra note 6, an employer must provide a first aid room if 200 or more employees are working at any time in a workplace. In Alberta (in a high-hazard work environment), Schedule 2, Table 7 of the OH\&S Code, ibid, requires an employer to provide a first aid room if the work site has over 100 workers at any time. Furthermore, section 7.4 of the Canada Regulations limits the sound exposure of an employee to $87 \mathrm{dBA}$ (Lex), however, in Alberta, section 217(1) of the OH\&S Code states that at all times, noise cannot exceed a level of $85 \mathrm{dBA}$ (Lex). These examples are not comprehensive of all of the technical and specific differences in the occupational health and safety requirements between federal and Alberta jurisdictions. Instead, the examples are provided to demonstrate that health and safety requirements between the jurisdictions are not uniform.
} 


\begin{tabular}{|c|c|c|c|}
\hline Requirement & Alberta OH\&S Legislation & Canada Labour Code & Commentary \\
\hline $\begin{array}{l}\text { Prime } \\
\text { Contractor }\end{array}$ & $\begin{array}{l}\text { Every work site must have a prime } \\
\text { contractor if there are } 2 \text { or more } \\
\text { employers involved in work at the } \\
\text { work site. [OH\&S Act, s 3(1)] }\end{array}$ & $\begin{array}{l}\text { Concept of prime contractor does } \\
\text { not exist. }\end{array}$ & $\begin{array}{l}\text { Prime contractor } \\
\text { responsibilities are found } \\
\text { throughout the } O H \& S \\
\text { Act. }\end{array}$ \\
\hline $\begin{array}{l}\text { Health and } \\
\text { Safety } \\
\text { Representative }\end{array}$ & $\begin{array}{l}\text { No statutory requirement for } \\
\text { health and safety representative in } \\
\text { a workplace. }\end{array}$ & $\begin{array}{l}\text { Every employer shall, for each work } \\
\text { place controlled by the employer at } \\
\text { which fewer than twenty employees } \\
\text { are normally employed or for which } \\
\text { an employer is not required to } \\
\text { establish a work place committee, } \\
\text { appoint the person selected in } \\
\text { accordance with subsection (2) as } \\
\text { the health and safety representative } \\
\text { for that work place. [CLC, s 136(1), } \\
\text { emphasis added] }\end{array}$ & $\begin{array}{l}\text { Threshold in federal } \\
\text { jurisdiction is fewer than } \\
20 \text { employees. }\end{array}$ \\
\hline $\begin{array}{l}\text { Joint Work } \\
\text { Site Health and } \\
\text { Safety } \\
\text { Committee } \\
\text { (in the federal } \\
\text { jurisdiction, } \\
\text { term is } \\
\text { "Workplace } \\
\text { Health and } \\
\text { Safety } \\
\text { Committee") }\end{array}$ & $\begin{array}{l}\text { The Minister may, by order, } \\
\text { require that there be established at } \\
\text { any work site a joint work site } \\
\text { health and safety committee that } \\
\text { shall } \\
\text { (a) identity situations that may be } \\
\text { unhealthy or unsafe in respect of } \\
\text { the work site, } \\
\text { (b) make recommendations to } \\
\text { prime contractors, contractors, } \\
\text { employers and workers for the } \\
\text { improvement of the health and } \\
\text { safety of workers at or on the } \\
\text { work site, } \\
\text { (c) establish and maintain } \\
\text { educational programs regarding } \\
\text { the health and safety of workers at } \\
\text { or on the work site, and } \\
\text { (d) carry out those duties and } \\
\text { functions provided for by the } \\
\text { adopted code. [OH\&S Act, s } 31(1) \text {, } \\
\text { emphasis added] }\end{array}$ & $\begin{array}{l}\text { For the purposes of addressing } \\
\text { health and safety matters that apply } \\
\text { to individual work places, and } \\
\text { subject to this section, every } \\
\text { employer shall, for each work place } \\
\text { controlled by the employer at which } \\
\text { twenty or more employees are } \\
\text { normally employed, establish a } \\
\text { workplace health and safety } \\
\text { committee and, subject to section } \\
\text { 135.1, select and appoint its } \\
\text { members. [CLC, s 135(1), emphasis } \\
\text { added] } \\
\text { Section 135(7) lists the duties of the } \\
\text { work place health and safety } \\
\text { committee. [CLC] }\end{array}$ & $\begin{array}{l}\text { In Alberta, the decision to } \\
\text { require a joint work site } \\
\text { health and safety } \\
\text { committee is discretionary } \\
\text { upon the Minister. } \\
\text { Federally, there is a } \\
\text { statutory requirement for } \\
\text { a workplace health and } \\
\text { safety committee if the } \\
\text { work place is controlled } \\
\text { by the employer and has } \\
20 \text { or more employees } \\
\text { normally employed. } \\
\text { Federally, section } \\
134.1(1) \text { of the } C L C \\
\text { requires that every } \\
\text { employer who normally } \\
\text { employs } 300 \text { or more } \\
\text { employees, establish a } \\
\text { policy committee in } \\
\text { addition to the workplace } \\
\text { health and safety } \\
\text { committee. }\end{array}$ \\
\hline $\begin{array}{l}\text { Liability for } \\
\text { Health and } \\
\text { Safety } \\
\text { Committee } \\
\text { Members }\end{array}$ & $\begin{array}{l}\text { No statutory immunity for joint } \\
\text { work site health and safety } \\
\text { committee members. }\end{array}$ & $\begin{array}{l}\text { No person serving as a member of a } \\
\text { committee is personally liable for } \\
\text { anything done or omitted to be done } \\
\text { by the person in good faith under } \\
\text { the authority or purported authority } \\
\text { of this Part. [CLC, s 135.1(13)] }\end{array}$ & $\begin{array}{l}\text { Statutory immunity is } \\
\text { only available in the } \\
\text { federal jurisdiction. }\end{array}$ \\
\hline
\end{tabular}




\begin{tabular}{|c|c|c|c|}
\hline Requirement & Alberta OH\&S Legislation & Canada Labour Code & Commentary \\
\hline $\begin{array}{l}\text { Health and } \\
\text { Safety Officers }\end{array}$ & $\begin{array}{l}\text { Section } 8 \text { of the } O H \& S \text { Act } \\
\text { outlines the statutory power and } \\
\text { authority of Health and Safety } \\
\text { Officers (known as "officers" in } \\
\text { the } O H \& S \text { Act). }\end{array}$ & $\begin{array}{l}\text { Section } 141 \text { of the } C L C \text { outlines the } \\
\text { statutory power and authority of } \\
\text { Health and Safety Officers. }\end{array}$ & $\begin{array}{l}\text { In Alberta, section 8(2) of } \\
\text { the OH\&S Act does not } \\
\text { permit an officer to } \\
\text { require production of, or } \\
\text { examine or make copies } \\
\text { of, medical reports or } \\
\text { records, or remove them } \\
\text { temporarily for the } \\
\text { purpose of making copies. } \\
\text { In the federal jurisdiction, } \\
\text { there are no such } \\
\text { restrictions. }\end{array}$ \\
\hline $\begin{array}{l}\text { Liability of } \\
\text { Health and } \\
\text { Safety Officers }\end{array}$ & $\begin{array}{l}\text { No statutory immunity for health } \\
\text { and safety officers. }\end{array}$ & $\begin{array}{l}\text { A health and safety officer is not } \\
\text { personally liable for anything done } \\
\text { or omitted to be done by the officer } \\
\text { in good faith under the authority or } \\
\text { purported authority of this Part. } \\
\text { [CLC, s } 141(8)]\end{array}$ & $\begin{array}{l}\text { Statutory immunity is } \\
\text { only available in the } \\
\text { federal jurisdiction. }\end{array}$ \\
\hline $\begin{array}{l}\text { Reporting } \\
\text { Requirements }\end{array}$ & $\begin{array}{l}\text { If an injury or accident described } \\
\text { in subsection (2) occurs at a work } \\
\text { site, the prime contractor or, if } \\
\text { there is no prime contractor, the } \\
\text { contractor or employer responsible } \\
\text { for that work site shall notify a } \\
\text { Director of Inspection of the time, } \\
\text { place and nature of the injury or } \\
\text { accident as soon as possible. } \\
\text { [OH\&S Act, s 18(1), emphasis } \\
\text { added] }\end{array}$ & $\begin{array}{l}\text { Without restricting the generality of } \\
\text { section 124, every employer shall, } \\
\text { in respect of every work place } \\
\text { controlled by the employer and, in } \\
\text { respect of every work activity } \\
\text { carried out by an employee in a } \\
\text { work place that is not controlled by } \\
\text { the employer, to the extent that the } \\
\text { employer controls the activity, } \\
\text {.. } \\
\text { (c) investigate, record and report in } \\
\text { the manner and to the authorities as } \\
\text { prescribed all accidents, } \\
\text { occupational diseases and other } \\
\text { hazardous occurrences known to the } \\
\text { employer; [CLC, s } 125(1)]\end{array}$ & \\
\hline $\begin{array}{l}\text { Incidents to be } \\
\text { Reported }\end{array}$ & $\begin{array}{l}\text { The injuries and accidents to be } \\
\text { reported under subsection (1) are } \\
\text { (a) an injury or accident that } \\
\text { results in death, } \\
\text { (b) an injury or accident that } \\
\text { results in a worker's being } \\
\text { admitted to a hospital for more } \\
\text { than } 2 \text { days, } \\
\text { (c) an unplanned or uncontrolled } \\
\text { explosion, fire or flood that causes } \\
\text { a serious injury or that has the } \\
\text { potential of causing a serious } \\
\text { injury, }\end{array}$ & $\begin{array}{l}\text { The employer shall report to a } \\
\text { health and safety officer, by } \\
\text { telephone or telex, the date, time, } \\
\text { location and nature of any accident, } \\
\text { occupational disease or other } \\
\text { hazardous occurrence referred to in } \\
\text { section } 15.4 \text { that had one of the } \\
\text { following results, as soon as } \\
\text { possible but not later than } 24 \text { hours } \\
\text { after becoming aware of that result, } \\
\text { namely, } \\
\text { (a) the death of an employee; }\end{array}$ & $\begin{array}{l}\text { In Alberta, pursuant to } \\
\text { section 18(3) of the } \\
\text { OH\&S Act, the prime } \\
\text { contractor, employer or } \\
\text { contractor for a work site } \\
\text { is required to investigate } \\
\text { and report on the } \\
\text { circumstances } \\
\text { surrounding an injury or } \\
\text { incident, whether or not } \\
\text { the incident meets any of } \\
\text { the five criteria listed in }\end{array}$ \\
\hline
\end{tabular}




\begin{tabular}{|c|c|c|c|}
\hline Requirement & Alberta OH\&S Legislation & Canada Labour Code & Commentary \\
\hline $\begin{array}{l}\text { Incidents to be } \\
\text { Reported } \\
\text { (con't) }\end{array}$ & $\begin{array}{l}\text { (d) the collapse or upset of a } \\
\text { crane, derrick or hoist, or } \\
\text { (e) the collapse or failure of any } \\
\text { component of a building or } \\
\text { structure necessary for the } \\
\text { structural integrity of the building } \\
\text { or structure. [OH\&S Act, s 18(2)] }\end{array}$ & $\begin{array}{l}\text { (b) a disabling injury to two or more } \\
\text { employees; } \\
\text { (c) the loss by an employee of a } \\
\text { body member or a part thereof or } \\
\text { the complete loss of the usefulness } \\
\text { of a body member or a part thereof; } \\
\text { (d) the permanent impairment of a } \\
\text { body function of an employee; } \\
\text { (e) an explosion; } \\
\text { (f) damage to a boiler or pressure } \\
\text { vessel that results in fire or the } \\
\text { rupture of the boiler or pressure } \\
\text { vessel; or } \\
\text { (g) any damage to an elevating } \\
\text { device that renders it unserviceable, } \\
\text { or a free fall of an elevating device. } \\
\text { [Canada Regulations, s 15.5, } \\
\text { emphasis added] } \\
\text { Schedule I of the Canada } \\
\text { Regulations further sets out the } \\
\text { actual information that is required to } \\
\text { be reported to the federal } \\
\text { authorities. }\end{array}$ & $\begin{array}{l}\text { section 18(2) of the } \\
\text { OH\&S Act. The report } \\
\text { must also include } \\
\text { corrective actions to } \\
\text { prevent reoccurrence. } \\
\text { There is no requirement in } \\
\text { Alberta to deliver a report } \\
\text { to a government health } \\
\text { and safety officer, unless } \\
\text { ordered to do so. } \\
\text { Federally-regulated } \\
\text { employers are required to } \\
\text { keep a record of each } \\
\text { minor injury of which the } \\
\text { employer is aware that } \\
\text { affects any employee in } \\
\text { the course of their } \\
\text { employment [Canada } \\
\text { Regulations, s } 15.7(1)] \text {. } \\
\text { Further, the Canada } \\
\text { Regulations require that } \\
\text { every employer submit an } \\
\text { annual report } \\
\text { summarizing all incidents, } \\
\text { occupational diseases and } \\
\text { incidents that occurred in } \\
\text { the previous year } \\
\text { [Canada Regulations, s } \\
\text { 15.10]. }\end{array}$ \\
\hline $\begin{array}{l}\text { Limitation } \\
\text { Periods }\end{array}$ & $\begin{array}{l}\text { A prosecution under this Act may } \\
\text { be commenced within } 2 \text { years after } \\
\text { the commission of the alleged } \\
\text { offence, but not afterwards. } \\
\text { [OH\&S Act, s 41(4), emphasis } \\
\text { added] }\end{array}$ & $\begin{array}{l}\text { Proceedings in respect of an offence } \\
\text { under this Part may be instituted at } \\
\text { any time within but not later than } \\
\text { one year after the time when the } \\
\text { subject-matter of the proceedings } \\
\text { arose. [CLC, s 149(4), emphasis } \\
\text { added] }\end{array}$ & $\begin{array}{l}\text { Limitation period in } \\
\text { Alberta is twice the length } \\
\text { of that which is found in } \\
\text { the federal jurisdiction. }\end{array}$ \\
\hline $\begin{array}{l}\text { Admissibility } \\
\text { of Evidence } \\
\text { provided in } \\
\text { Report }\end{array}$ & $\begin{array}{l}\text { A report prepared under this } \\
\text { section is not admissible as } \\
\text { evidence for any purpose in a trial } \\
\text { arising out of the serious injury or } \\
\text { accident, an investigation or } \\
\text { public inquiry under the Fatality } \\
\text { Inquiries Act or any other action }\end{array}$ & $\begin{array}{l}\text { No restriction on admissibility of } \\
\text { evidence. }\end{array}$ & $\begin{array}{l}\text { A similar provision is } \\
\text { found in section 19(5) of } \\
\text { the OH\&S Act restricting } \\
\text { admissibility of } \\
\text { statements provided in } \\
\text { incident investigations. }\end{array}$ \\
\hline
\end{tabular}




\begin{tabular}{|c|c|c|c|}
\hline Requirement & Alberta OH\&S Legislation & Canada Labour Code & Commentary \\
\hline $\begin{array}{l}\text { Admissibility } \\
\text { of Evidence } \\
\text { provided in } \\
\text { Report (con't) }\end{array}$ & $\begin{array}{l}\text { as defined in the Alberta Evidence } \\
\text { Act except in a prosecution for } \\
\text { perjury or for the giving of } \\
\text { contradictory evidence. [OH\&S } \\
\text { Act, s 18(5)] }\end{array}$ & & \\
\hline Penalties & $\begin{array}{l}\text { A person who contravenes this } \\
\text { Act, the regulations or an adopted } \\
\text { code or fails to comply with an } \\
\text { order made under this Act, the } \\
\text { regulation or an adopted code or } \\
\text { with an acceptance issued under } \\
\text { this Act is guilty of an offence and } \\
\text { liable } \\
\text { (a) for a first offence, } \\
\text { (i) to a fine of not more than } \\
\$ 500,000 \text { and in the case of a } \\
\text { continuing offence, to a further } \\
\text { fine of not more than } \$ 30,000 \text { for } \\
\text { each day during which the offence } \\
\text { continues after the first day or part } \\
\text { of a day, or } \\
\text { (ii) to imprisonment for a term not } \\
\text { exceeding } 6 \text { months, or to both } \\
\text { fines and imprisonment, and } \\
\text { (b) for a } 2 n d \text { or subsequent } \\
\text { offence, } \\
\text { (i) to a fine of not more than } \\
\$ 1,000,000 \text { and in the case of a } \\
\text { continuing offence, to a further } \\
\text { fine of not more than } \$ 60,000 \text { for } \\
\text { each day or part of a day during } \\
\text { which the offence continues after } \\
\text { the first day, or } \\
\text { (ii) to imprisonment for a term not } \\
\text { exceeding } 12 \text { months, or to both } \\
\text { Act, s } 41(1) \text {, emphasis added] }\end{array}$ & $\begin{array}{l}\text { Subject to this section, every person } \\
\text { who contravenes a provision of this } \\
\text { Part is guilty of an offence and } \\
\text { liable } \\
\text { (a) on conviction on indictment, to a } \\
\text { fine of not more than } \$ 1,000,000 \text { or } \\
\text { to imprisonment for a term of not } \\
\text { more than two years, or to both; or } \\
\text { (b) on summary conviction, to a fine } \\
\text { of not more than } \$ 100,000 \text {. } \\
\text { (2) Every person who contravenes a } \\
\text { provision of this Part the direct } \\
\text { result of which is the death of, } \\
\text { serious illness of or serious injury to } \\
\text { an employee is guilty of an offence } \\
\text { and liable } \\
\text { (a) on conviction on indictment, to a } \\
\text { fine of not more than } \$ 1,000,000 \text { or } \\
\text { to imprisonment for a term of not } \\
\text { more than two years, or to both; or } \\
\text { (b) on summary conviction, to a fine } \\
\text { of not more than } \$ 1,000,000 \text {. [CLC, } \\
\text { of not more than } \$ 1,000,000 \text {. } \\
\text { (3) Every person who wilfully } \\
\text { contravenes a provision of this Part } \\
\text { knowing that the contravention is } \\
\text { likely to cause the death of, serious } \\
\text { illness of or serious injury to an } \\
\text { employee is guilty of an offence and } \\
\text { liable } \\
\text { (a) on conviction on indictment, to a } \\
\text { fine of not more than } \$ 1,000,000 \text { or } \\
\text { to thent for a term of not } \\
\text { added] }\end{array}$ & $\begin{array}{l}\text { Financial penalties and } \\
\text { imprisonment terms vary } \\
\text { significantly between } \\
\text { Alberta and the federal } \\
\text { jurisdiction. } \\
\text { The OH\&S Act does not } \\
\text { differentiate between } \\
\text { indictable and summary } \\
\text { convictions in the penalty } \\
\text { provisions as done in the } \\
\text { CLC. } \\
\text { All penalties are in } \\
\text { addition to any penalties } \\
\text { that may be imposed by } \\
\text { the Criminal Code. }\end{array}$ \\
\hline
\end{tabular}


The most significant differences between the two jurisdictions that an employer should be aware of are those regarding:

- $\quad$ reporting requirements;

- $\quad$ admissibility of evidence where an incident has occurred;

- $\quad$ length of the limitation periods; and

- $\quad$ penalty provisions.

\section{CONSTITUTIONAL BACKGROUND}

Sections 91(29) and 92(10) of the Constitution Act, 1867 give Parliament jurisdiction over subjects such as railways, canals, telegraphs, and other works and undertakings connecting one province with any other or that extend beyond the limits of the province. ${ }^{11}$

Not only are federally-regulated works and undertakings beyond the jurisdiction of provincial regulators, the inter-jurisdictional immunity doctrine decrees that a federal work or undertaking will not be subject to provincial regulation where such regulation would impact a vital or essential matter which is beyond the jurisdiction of the provincial government.

Courts have been struggling to define whether works and undertakings are federally or provincially regulated since 1867 . Parliament has exclusive legislative jurisdiction over labour relations and working conditions when that jurisdiction is an integral part of its primary and exclusive jurisdiction over federal undertakings such as interprovincial telephone operations, railways and trucking companies (as discussed below), and pipelines (as discussed below).

This jurisdiction precludes the application of provincial statutes "relating to labour relations and working conditions, since such matters are an essential part of the very management and operation of such undertakings, as with any commercial or industrial undertaking." 12

The Supreme Court of Canada has held that legislation relating to working hours is within the exclusive jurisdiction of Parliament because it deals with working conditions. ${ }^{13}$ In the Bell Canada 1988 case, discussed below, the Supreme Court of Canada held that legislation regulating health and safety was, in fact, regulating an aspect of working conditions and therefore was exclusive to Parliament when dealing with federal undertakings. ${ }^{14}$

$11 \quad$ Supra note 2, ss 91(29), 92(10).

12 Bell Canada v Quebec (Commission de la santé et de la sécurité du travail), [1988] 1 SCR 749 [Bell Canada 1988].

13 Reference re Minimum Wage Act of Saskatchewan, [1948] SCR 248 [Postal Service Case 1948]; Commission du Salaire Minimum v Bell Telephone Company of Canada, [1966] SCR 767 [Bell Canada 1966].

$14 \quad$ Supra note 12. 
In contrast to that finding on occupational health and safety, the Supreme Court of Canada has also ruled that provincial workers' compensation schemes are applicable to federal undertakings because they do "not purport to regulate the contract of employment." 15 An examination of what constitutes a federal work or undertaking follows.

\section{THE TESTS TO DETERMINE FEDERAL or PRovincial JURISDiction}

Typically, an entity is examined to determine whether its works and undertakings are such that it would be found to be under federal jurisdiction. The entity will be federally governed if it either constitutes a single federal work or undertaking or is integral to a federal undertaking. ${ }^{16}$

In Westcoast, ${ }^{17}$ the Supreme Court of Canada examined what constituted a federal work or undertaking. ${ }^{18}$ Because the Supreme Court of Canada found that the Westcoast project was a federal work or undertaking, the Court declined to examine the second test as to whether the project was "integral" to a federal undertaking. More recently, in Tessier, ${ }^{19}$ the Supreme Court of Canada identified the conditions that would cause a project to be considered "integral” to a federally-regulated undertaking.

\section{A. What Constitutes A SingLE FEDERAL WORK OR UNDERTAKING?}

The Supreme Court of Canada's decision in Westcoast arose out of Westcoast Energy's application to the National Energy Board (NEB) for permission:

- $\quad$ in the vicinity of its Fort St. John processing plant, to expand gathering pipelines, build three new compressor facilities, and construct a new processing plant, and

- $\quad$ in the vicinity of the Grizzly Valley area, to construct an additional loop on one gathering pipeline and several new gathering pipelines, expand a processing plant, build a fuel gas pipeline, build a loop to increase the capacity of the main line pipeline, and upgrade a compressor unit.

Bell Canada 1966, supra note 13 at 774.

See United Transportation Union v Central Western Railway Corp, [1990] 3 SCR 1112.

Westcoast Energy Inc v Canada (National Energy Board), [1998] 1 SCR 322 [Westcoast].

The argument was made unsuccessfully in Westcoast that section 92A confers powers on the provinces that would otherwise be within the jurisdiction of Parliament. Section 92A was enacted in 1982 to give the provinces greater authority over the development, conservation, and management of natural resources and the facilities for the generation of electricity. In Westcoast, the Supreme Court of Canada, at para 81, quoted from Ontario Hydro v Ontario (Labour Relations Board), [1993] 3 SCR 327, which found that section 92A did not diminish Parliament's powers, but gave the provinces the authority to "legislate for the export of resources to other provinces subject to Parliament's paramount legislative power in the area, as well as to permit indirect taxation in respect of resources so long as such taxes do not discriminate against other provinces" (Westcoast, ibid at para 83.) At the end of the day, while section 92A may give certain powers to the provinces, it did not take away the jurisdiction of Parliament.

19 Tessier Ltée v Quebec (Commission de la santé et de la sécurité du travail), 2012 SCC 23, [2012] 2 SCR 3 [Tessier]. 
The NEB found it did not have jurisdiction. However, that decision was overturned by the Federal Court of Appeal. ${ }^{20}$ The determination of the Federal Court of Appeal that the NEB did have jurisdiction was upheld by a majority of the Supreme Court of Canada. ${ }^{21}$

The Supreme Court of Canada summarized the division of powers between the provincial and federal jurisdictions as follows:

Subsection 92(10) of the Constitution Act, 1867 provides generally that local works and undertakings within a province come within provincial jurisdiction. However, the combined effect of ss. 91(29) and 92(10)(a) creates an exception whereby Parliament has exclusive jurisdiction over works and undertakings that come within the phrase "Lines of Steam or other Ships, Railways, Canals, Telegraphs, and other Works and Undertakings connecting the Province with any other or others of the Provinces, or extending beyond the Limits of the Province” in s. 92(10)(a). The effect of s. 92(10)(a) is that interprovincial transportation and communications works and undertakings fall within federal jurisdiction. ${ }^{22}$

Following this, the Supreme Court of Canada reviewed earlier decisions that defined the terms "works” and "undertakings":

\begin{abstract}
Section 92(10)(a) refers to both "works" and "undertakings". "Works" were defined in City of Montreal v Montreal Street Railway ... as "physical things, not services”. Since the proposed gathering pipeline and processing plant facilities will be located entirely within the province of British Columbia, it seems clear that they would constitute local works. As a result, the submissions of the parties concentrated on whether Westcoast operated a single federal undertaking. “Undertaking” was defined in Re Regulation \& Control of Radio Communication ... as "not a physical thing but ... an arrangement under which ... physical things are used". Professor Hogg concludes in Constitutional Law of Canada ... that the term "undertaking" appears to be equivalent to "organization” or "enterprise”. In Alberta Government Telephones ... Dickson C.J. stated ... that " $[t]$ he primary concern is not the physical structures or their geographical location, but rather the service which is provided by the undertaking through the use of its physical equipment."23
\end{abstract}

Based on the definitions of "works" and "undertakings," the Court in Westcoast focused on whether Westcoast was a single federal undertaking. The main characteristics of an operation that is a single federal undertaking are:

(1) functional integration;

(2) common management, control, and direction; and

(3) operation as a single enterprise. ${ }^{24}$

Westcoast Energy Inc v Canada (National Energy Board), [1996] 2 FC 263, 134 DLR (4th) 114.

Note, however, a strong dissent was written by Chief Justice McLachlin (Westcoast, supra note 17 at para 90).

Ibid at para 43.

Ibid at para 47 [emphasis added].

Ibid at para 49. 
Other considerations include "whether the operations are under common ownership ... and whether the goods or services provided by one operation are for the sole benefit of the other operation and/or its customers, or whether they are generally available."25

In relation to whether the goods and services are generally available, scenarios could include situations where one aspect of a business is dedicated exclusively or even primarily to the operation of the core interprovincial undertaking. ${ }^{26}$ Examples of cases where the analysis of the court has focused on the interrelationship between the core undertaking and the operation at issue are:

- $\quad$ the Empress Hotel ${ }^{27}$ case where the Privy Council suggested that a hotel that was built solely or principally for the benefit of railway passengers of a particular company might be part of that railway company's federal undertaking (though this was not found to be the case in relation to the Empress Hotel in Victoria); and

- $\quad$ the Dome Petroleum ${ }^{28}$ case where underground storage caverns were found to form part of an interprovincial natural gas pipeline undertaking because they were provided solely for the benefit of the shippers and were provided by the owner of the pipeline.

Although the Court in Westcoast specifically declined to address the question of whether Westcoast's facilities were "integral" to the federal undertaking, the scenarios discussed above seem to answer the question of what a court would look at to determine whether a particular operation was integral to a federal undertaking. In fact, the Federal Court of Appeal in Dome Petroleum said that the "storage caverns are an integral and essential part of [Dome's] ... system."29

A scenario that did not meet the test of being a single federal undertaking occurred in the

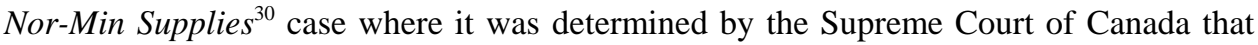
having a quarry adjacent to a railway which was used exclusively to provide ballast for the railway, did not meet the test of being a single federal undertaking. Commenting on the NorMin Supplies case in Westcoast, the Supreme Court of Canada said that exclusive or primary dedication of a local operation to a core interprovincial federally-regulated undertaking supports a finding of a single federal undertaking, but it is only one factor. The Court said "the overall degree of functional integration and common management" 31 must also be assessed.

Ibid at para 65 .

Ibid at para 54

Canadian Pacific Railway Co v British Columbia (AG), [1950] AC 122 HL (Eng) [Empress Hotel]. Dome Petroleum Ltd v National Energy Board (1987), 73 NR 135 (FCA) [Dome Petroleum]. Ibid at para 18.

Canadian National Railway Co v Nor-Min Supplies Ltd, [1977] 1 SCR 322 [Nor-Min Supplies]. Westcoast, supra note 17 at para 57. 


\section{B. IS THE WORK “INTEGRAL” TO THE FEDERAL UNDERTAKING?}

\section{FUNCTIONALLY DisCREET}

In Tessier, the parent company of Tessier Ltée, a heavy equipment rental company, sought a declaration that it was subject to federal jurisdiction so that it could avoid payment of certain provincial levies relating to occupational health and safety. The case was heard by the Supreme Court of Canada, which analyzed the conditions under which Parliament has jurisdiction to regulate labour relations. The Court considered the instances where employment would be "integral" to the federally-regulated undertaking, also known as the derivative approach.

Relying upon the Supreme Court of Canada's decision in the Stevedores Reference, ${ }^{32}$ where stevedoring activities were found to be within Parliament's jurisdiction, Tessier argued that because a section of its business involved stevedoring activities, the regulation of its activities should also fall under auspices of federal control.

In a unanimous decision, the Supreme Court of Canada found that the activities of Tessier did not fall within the sphere of Parliament, but were to be regulated under provincial occupational health and safety laws. The general principles from this decision are summarized succinctly in the headnote:

\footnotetext{
Federal labour regulation may be justified when the services provided to the federal undertaking form the exclusive or principal part of the related work's activities. It may also be justified when the services provided to the federal undertaking are performed by employees who form a functionally discrete unit that can be constitutionally characterized separately from the rest of the related operation. If the employees performing the work do not form a discrete unit and are fully integrated into the related operation, then even if the work of those employees is vital to the functioning of a federal undertaking, it will not render federal an operation that is otherwise local if the work represents an insignificant part of the employees' time or is a minor aspect of the essential ongoing nature of the operation. ${ }^{33}$
}

Whether employment is integral to a federal undertaking, was also considered by the Supreme Court of Canada:

This appeal is the first time that this Court has had the opportunity to assess the constitutional consequences when the employees performing the work do not form a discrete unit and are fully integrated into the related operation. It seems to me that even if the work of those employees is vital to functioning of a federal undertaking, it will not render federal an operation that is otherwise local if the work represents an insignificant part of the employees' time or is a minor aspect of the essential ongoing nature of the operation. 
In this sense, Tessier's acknowledgment that it operates an indivisible undertaking works against its position that its stevedoring employees render the whole company subject to federal regulation. If Tessier itself was an inter-provincial transportation undertaking, it would be justified in assuming that the percentage of its activities devoted to local versus extra-provincial transportation would not be relevant... But since Tessier can only qualify derivatively as a federal undertaking, federal jurisdiction is only justified if the federal activity is a significant part of its operation.

In short, if there is an indivisible, integrated operation, it should not be artificially divided for purposes of constitutional classification. Only if its dominant character is integral to a federal undertaking will a local work or undertaking be federally regulated; otherwise, jurisdiction remains with the province. ${ }^{34}$

Clouding the issue and adding to the complexity of finding a simple answer to jurisdictional questions regarding occupational health and safety, the Supreme Court of Canada in Tessier appeared to abandon the majority decision in Westcoast in favour of the dissenting opinion of Chief Justice McLachlin. In discussing the Westcoast decision in Tessier, the Court stated:

\begin{abstract}
McLachlin J., writing in dissent, framed the case differently and in a way that is of particular assistance in this case. After noting that the gathering and processing plants themselves were not inter-provincial transportation undertakings (the direct jurisdiction test), she held that they could only be subject to federal regulation if they were integral to the inter-provincial pipelines. In applying the derivative approach, she emphasized that exceptional federal jurisdiction would only be justified when the related operation was functionally connected to the federal undertaking in such an integral way that it lost its distinctive provincial character and moved into the federal sphere.... She considered the common management of and interconnection between the facilities and the pipeline and the dependency of the pipeline on the facilities and concluded that the facilities retained their distinct non-transportation identity. They were not vital, in the requisite constitutional sense, to the inter-provincial pipeline. ${ }^{35}$
\end{abstract}

While Tessier has provided helpful commentary to any analysis of the second part of the jurisdictional test, a clear answer as to whether employment matters should be governed by federal or provincial legislation can still be elusive.

\title{
2. PHYSICAL AND OPERATION INTEGRATION
}

In the same vein as Tessier, the Ontario Court of Appeal in R. v. EllisDon Corporation $L t d .^{36}$ found that provincial occupational health and safety laws applied to employees working on an expansion project at Pearson International Airport. The case arose in the context of charges under the Ontario Occupational Health and Safety Act ${ }^{37}$ against the general contractor EllisDon Corporation Ltd. (EllisDon), its subcontractor Blenkhorn-Sayers Structural Steel Corp. (Blenkhorn), and some individual workers after one of Blenkhorn's workers was injured. 
The degree of physical and operational integration between the EllisDon and Blenkhorn, on the one hand, and the airport authority, on the other hand, fell short of the degree required to invoke federal jurisdiction over the work. The work performed by EllisDon on the airport project was between 3 percent and 15 percent of its operations as a whole, and the work performed by Blenkhorn on the airport project was approximately 29 percent of its operations as a whole. Neither EllisDon nor Blenkhorn had formed a separate unit or division for airport work, though they both had employees who specialized in airport development. Most of the other work performed by EllisDon and Blenkhorn was provincial in nature. Quoting the Supreme Court of Canada in Northern Telecom No. 2, ${ }^{38}$ Justice Sharp in EllisDon reiterated that 80 percent of the workforce performing a certain category of work was "very close to the boundary line between federal and provincial jurisdiction.”39

\section{Close Functional RELATIONSHIP}

In Northern Telecom No. $2,^{40}$ the Supreme Court of Canada dealt with the issue of jurisdiction in the context of whether the federal or provincial laws applied to the labour relations of a group of Northern Telecom employees. Northern Telecom was not a federallyregulated business, but the unions involved sought certification pursuant to the Canada Labour Code. The Canada Labour Relations Board determined that the employees in the eastern region were not governed by federal labour laws and brought a reference case in the Federal Court of Appeal. ${ }^{41}$ The Federal Court of Appeal overturned the decision and found that the federal laws did apply to the collective bargaining.

The employees in the eastern region operated as an independent unit performing installations, consisting mostly of Northern Telecom equipment, in the telephone network operated by Bell Canada. All parties agreed that Bell Canada was a federal undertaking. A majority of the Supreme Court of Canada agreed with the Federal Court of Appeal that the collective bargaining unit was federally regulated because the "installers ... are not engaged in the manufacture of ... equipment ... but only in its installation, and 80 per cent of this work is carried out on Bell premises." ${ }^{42}$ Another key factor was that the Court found that there was a "close functional relationship of the work of the installers to the operation of the Bell undertaking" that required the Court to regard these employees as "employed upon or in connection with the operation of the Bell undertaking." 43

\section{ESSENTIAL OPERATIONAL NATURE}

The Alberta Court of Queen's Bench has also had the opportunity to weigh-in on this pithy topic in Total Oilfields Rentals. ${ }^{44}$ Relying on Tessier, Justice Hall set out the test for determining whether there is direct federal jurisdiction as follows:

Northern Telecom v Communication Workers, [1983] 1 SCR 733 [Northern Telecom No 2].

Supra note 36 at para 39.

Supra note 38.

Re Communications Workers of Canada v Northern Telecom Canada Ltd, [1982] 1 FC 191

[Communications Workers].

Northern Telecom No 2, supra note 38 at 739.

Ibid, citing Communications Workers, supra note 41 at 203.

Total Oilfield Rentals Limited Partnership v Canada (AG), 2013 ABQB 263, 227 ACWS (3d) 1005

[Total Oilfield Rentals]. 
The Applicant states, and the Respondents concede that the question of whether an undertaking, service or business is Provincial or Federal depends upon the nature of its operation. The Court must assess whether the business or undertaking's essential operational nature brings it within a federal head of power. In order to determine the nature of an operation, the Court must look at the normal or habitual activities of the business as a going concern. The exceptional aspects of an enterprise do not determine its essential operational nature. It is the essential nature of the undertaking that determines constitutional jurisdiction. ${ }^{45}$

Total Oilfield Rentals was in the business of renting oilfield equipment and, as it was based in Alberta and operated in several provinces, often found itself transporting the equipment between provinces. Charges were laid against Total Oilfield Rentals under the Canada Labour Code as federal regulators took the position that it was a federal undertaking and was required to operate in accordance with federal laws. ${ }^{46}$ In the Alberta Court of Queen's Bench, Justice Hall disagreed and found that the interprovincial transportation of the equipment was ancillary to the rental business. Justice Hall found authority for this position in Conklin \& Garrett Ltd. $v$ Ontario ${ }^{47}$ where the Ontario Divisional Court found that an amusement ride operator who transported its equipment interprovincially did not transform the operator into an interprovincial transport company.

\section{The Pith And Substance of OCCUPATIONAL HEALTH AND SAFETY LEgISLATION}

Ultimately, the division of constitutional powers determines the allocation of responsibility for occupational health and safety matters where federal undertakings are involved.

In the case of localized provincial undertakings being undertaken by a provinciallyregulated owner, the provincial legislation will govern. However, sections 91(29) and 92(10) of the Constitution Act, 1867 address the allocation of responsibility between federal and provincial governments by providing that legislation that affects the management of federal undertakings is within the exclusive jurisdiction of the Parliament of Canada. ${ }^{48}$ The seminal cases relating to occupation health and safety are the trilogy of Bell Canada 1988, ${ }^{49}$ Canadian National, ${ }^{50}$ and Alltrans. ${ }^{51}$

The Supreme Court of Canada has considered the interplay of federal and provincial jurisdiction as it relates to occupational health and safety in Bell Canada 1988. In that case, a pregnant employee of Bell Canada had reservations about working in front of a video display terminal and, although the employee was offered another position, she eventually provided her supervisor with a protective re-assignment certificate pursuant to the Quebec

$45 \quad$ Ibid at para 5.

$46 \quad$ Canada (AG) v Total Oilfield Rentals Limited Partnership Inc, 2012 FC 321.

47 Conklin \& Garrett Ltd v Ontario (Director of the Elevating Devices Branch of the Ministry of Consumer and Commercial Relations (1989), 70 OR (2d) 713 (Div Ct).

48 There are a number of theories for determining whether provincial or federal law applies in a given situation, but, as it relates to the management of federal undertakings it is an issue of exclusive jurisdiction. See, for example, the doctrine of paramountcy, the double aspect theory, the concept of impairment, and others.

Supra note 12.

Canadian National Railway Co v Courtois, [1988] 1 SCR 868 [Canadian National].

Alltrans Express Ltd v British Columbia (Workers'Compensation Board), [1988] 1 SCR 897 [Alltrans]. 
Act respecting occupational health and safety. ${ }^{52}$ Bell Canada challenged the protective reassignment certificate on the basis of the Quebec Act not being applicable.

Bell Canada 1988 is part of a trilogy of cases which also included two other cases dealing with:

- the collision of two trains in Quebec resulting in three fatalities and an investigation of Canada National Railway under the Quebec Act; ${ }^{53}$ and

- $\quad$ orders made against Alltrans Express Ltd., an Ontario-based interprovincial and international trucking company, in relation to the operations at its Burnaby depot pursuant to those portions of the British Columbia Workers Compensation Act ${ }^{54}$ dealing with occupational health and safety. ${ }^{55}$

In all cases in the trilogy, the Supreme Court of Canada found that the pith and substance of the occupational health and safety legislation in those jurisdictions was working conditions, labour relations and management of an undertaking, all of which are within the exclusive jurisdiction of Parliament for federally-regulated entities.

Based on this characterization of the occupational health and safety legislation, the Supreme Court of Canada held that the impugned sections of the Quebec Act were not applicable to Bell Canada because they encroached on the exclusive federal jurisdiction relating to working conditions and labour relations. The Court found that neither the "Double Aspect Theory" 56 nor the "Concept of Impairment" 57 could be called upon to apply the Quebec Act because what it was trying to legislate was in the exclusive jurisdiction of Parliament. The headnote says, in part:

\section{Inapplicability of provincial legislation}

Although the objective of the [Quebec] Act respecting occupational health and safety is the elimination, at the source, of dangers to the health, safety and physical well-being of workers, a detailed analysis of the whole of its provisions demonstrates that the pith and substance of the Act is working conditions, labour relations and the management of an undertaking. In entering the field of prevention of accidents in the

RSQ 1979, с S-2.1.

Canadian National, supra note 50.

RSBC 1979, c 437.

Alltrans, supra note 51.

See Bell Canada 1988, supra note 12 at 765, where the Supreme Court of Canada refers to Hodge $v$ The Queen (1883), 9 App Cas 117 at 130, which described the Double Aspect Theory as being: "subjects which in one aspect and for one purpose fall within sect. 92, may in another aspect and for another purpose fall within sect. 91.”

$57 \quad$ See Bell Canada 1988, ibid at 860, describing the “Concept of Impairment” as follows:

If the application of a provincial statute to a federal undertaking has the effect of impairing or paralyzing it, that a fortiori is an almost certain sign that such application bears upon the specifically federal nature of the undertaking and constitutes an encroachment on the exclusive legislative authority of Parliament.

The concept of impairment apparently originated in decisions of the Judicial Committee when it had to be decided the extent to which federally incorporated companies are subject to provincial statutes which are general in application, and in particular to the general companies legislation in effect in a province. 
workplace ... the legislator entered directly and massively into the field of working conditions and labour relations ... and ... into the field of the management and operation of undertakings. In doing so, the legislator precluded itself from aiming at and regulating federal undertakings by the Act.

The Act, characterized as above, cannot be applied to ... federal undertakings ... without regulating essential parts of those undertakings.... For federal undertakings, working conditions and labour relations are matters falling within the classes of subject mentioned in s. 91(29) of the Constitution Act, 1867, and consequently are within the exclusive jurisdiction of Parliament. It follows that this primary and exclusive jurisdiction precludes the application to those undertakings of provincial statutes relating to labour relations and working conditions, since such matters are an essential part of the very management and operation of such undertakings, as with any commercial or industrial undertaking. This is one facet of a more general rule ... against making works, things or persons under the special and exclusive jurisdiction of Parliament subject to provincial legislation, when such application would bear on the specifically federal nature of the jurisdiction to which such works, things or persons are subject. Since these matters are within the exclusive authority of Parliament, it is not necessary to consider whether there is a conflict between the federal and provincial legislation. ${ }^{58}$

Based on the trilogy, all provincial occupational health and safety legislation will be characterized as interference with the management of an undertaking. As such, provincial occupational health and safety legislation cannot be applied to federal undertakings which are referred to in section 91(29) and sections 92(10)(a), (b), and (c) of the Constitution Act, 1867, as they are within the exclusive jurisdiction of Parliament.

\section{Determining Which Regime ApPlies to Contractors}

\section{A. Contractors Are Not All Provincially Regulated}

In Canadian Employment Law, ${ }^{59}$ the authors depart from the trilogy and suggest:

[T]here is a distinction made both in legislation and practice regarding safety in construction. Generally, safety in construction is governed by provincial regulation.

In particular, the standards, methods and procedures required for construction safety fall under the umbrella of provincial and territorial regulation. Further, the Supreme Court of Canada noted a distinction between the actual physical construction of a federally governed undertaking and the designing or planning of such an undertaking, and has held that the former falls short of the "integral" test and thereby falls outside of federal competency.

In summary, the safety of workers at construction sites is governed by provincial legislation, regardless of whether or not the project is a federally regulated business, work or undertaking. ${ }^{60}$

It is submitted that the above analysis is incorrect. Although it is possible that the majority of projects are governed by provincial occupational health and safety legislation, that is a 
function only of the majority of projects being within provincial jurisdiction. To make the statement that "safety is generally governed by provincial regulation," the authors of Canadian Employment Law rely on the Supreme Court of Canada's 1979 decision in Montcalm, ${ }^{61}$ which predates the Bell Canada 1988 trilogy. The Court in Bell Canada 1988 did not overrule Montcalm, however, stating that the decision in Montcalm was not at odds with the Bell Canada 1966 reasoning, which was adopted in the Bell Canada 1988 trilogy. ${ }^{62}$

\section{B. The Provincial Contractor Working ON A FEDERALly-REgulated PROJECT}

Montcalm dealt with the assertion of the Quebec Minimum Wage Commission that Construction Montcalm Inc. (Montcalm) was liable for levies and penalties in the amount of $\$ 13,481.24$ that it had imposed. Montcalm was a contractor working on the runways at the then new Mirabel airport on federal Crown land.

Montcalm argued that the Commission had no jurisdiction because the federal jurisdiction over aeronautics covered both airports and the construction of airports. Further, as a contractor on the federally regulated airport construction, it was not subject to provincial legislation. The majority of the Supreme Court of Canada found that:

\footnotetext{
The construction of an airport is not in every respect an integral part of aeronautics. Much depends on what is meant by the word "construction". To decide whether to build an airport and where to build it involves aspects of airport construction which undoubtedly constitute matters of exclusive federal concern.... Similarly, the design of a future airport, its dimensions, the materials to be incorporated into the various buildings, runways and structures, and other similar specifications are, from a legislative point of view and apart from contract, matters of exclusive federal concern. The reason is that decisions made on these subjects will be permanently reflected in the structure of the finished product and are such as to have a direct effect upon its operational qualities and, therefore, upon its suitability for the purposes of aeronautics. But the mode or manner of carrying out the same decisions in the act of constructing an airport stand on a different footing. Thus, the requirement that workers wear a protective helmet on all construction sites including the construction site of a new airport has everything to do with construction and with provincial safety regulations and nothing to do with aeronautics.... See also ... Vipond Automatic Sprinkler ... where Cavanagh J. of the Alberta Supreme Court held that "the fact of construction of a building called an air terminal does not ... show that the construction is connected with aeronautics" and that, while an aerodrome is a federal work, employees constructing such a building are subject to provincial labour relations legislation. ${ }^{63}$
}

The Supreme Court of Canada concluded that Montcalm was not a federally-regulated undertaking. The mere fact that it was a construction company working on a federallyregulated project did not make the construction company a federally-regulated undertaking. This was the same conclusion that the Ontario Court of Appeal arrived at nearly 30 years later in the EllisDon case. ${ }^{64}$ 
Many locally-based contractors and provincially-regulated contractors work on federallyregulated projects. Just because a small gravel company based in, and doing business solely in, Alberta provides gravel to an interprovincial pipeline, does not make it a federallyregulated business, and the provincial occupational health and safety legislation will still apply to it. As noted above, this rationale was recently confirmed by the Supreme Court of Canada in Tessier. ${ }^{65}$

\section{WHEN IS A CONTRACTOR FEDERALLY REGULATED?}

In $R$ v. O.J. Pipelines Inc., ${ }^{66}$ the Ontario Court of Appeal considered O.J. Pipelines' application to have it declared to be a federally-regulated entity and therefore not subject to the Ontario Occupational Health and Safety Act. ${ }^{67}$

O.J. Pipelines, incorporated in Alberta and licenced to do business in Ontario, was constructing an interprovincial pipeline owned by TransCanada when a fatality occurred. Both the NEB and Ontario Ministry of Labour investigated. The NEB found no violation, but the Ontario Ministry of Labour subsequently charged O.J. Pipelines with offences under the Ontario Occupational Health and Safety Act. The case came before the Ontario Court of Appeal as a result of an application by O.J. Pipelines to have the provincial charges dismissed for want of jurisdiction because, O.J. Pipelines argued, the Ontario Occupational Health and Safety Act could not apply to a federally-regulated project. The Ontario Ministry of Labour argued that the federal laws only applied to the owner, TransCanada, and not the contractor.

The Court found the application to be premature and deemed that it should be heard at trial. This decision was upheld on appeal. There is no reported trial decision. ${ }^{68}$

In $R v$ LeBlanc \& Royle Telcom Inc, ${ }^{69}$ the employer, LeBlanc \& Royle Telcom Inc., was charged under the Ontario Occupational Health and Safety Act after an employee fell to his death while working on the construction of a telecommunication tower. A five day trial was held on the jurisdictional issue at the provincial court level, and that decision was upheld by both the Ontario Superior Court trial and appellate levels.

The Ontario Court of Appeal described the facts of the case as follows:

$65 \quad$ Supra note 19.

66 (1992), 6 COHSC 169 (Ont CA) [OJ Pipelines].

67 RSO 1990, с O.1.

68 The authors of Canadian Employment Law, supra note 59 at 23-4, section 23:30 state:

In any event, the courts have stated that to determine whether or not a company is a federally regulated enterprise, a careful analysis of the actual workings of the company in relation to its customers must be done, including an analysis to determine whether the applicant company is merely a supplier to the industry in question or whether its operations are so integral to that industry that the applicant must be considered to be actually part of the industry itself [footnote omitted].

Although the OJ Pipelines case is referenced by the authors, it is submitted that it does not stand for the proposition suggested, but rather is just an example of the type of application that can be made at the appropriate time. 
The business of LeBlanc and its related companies is designing, building, erecting, inspecting, maintaining and repairing tele-communications towers, including antennae, and providing emergency services. The respondent is federally incorporated. The headquarters of the LeBlanc group is in Oakville, Ontario. Its four major divisions are engineering, products, services and financial and administration. The only part of the business involved in this case consists of the field crews; they are part of "services" and are located in six offices across Canada. ${ }^{70}$

Based on Bell Canada 1988, the Court of Appeal accepted that the occupational health and safety law was "subsumed" under the concept of "labour relations." The Court then looked at the leading case on determining which level of government has jurisdiction in labour relations: Northern Telecom No. $1{ }^{71}$ In Northern Telecom No. 1, the Supreme Court of Canada set out the procedure for determining when the federal government will have jurisdiction:

First, one must begin with the operation which is at the core of the federal undertaking. Then the courts look at the particular subsidiary operation engaged in by the employees in question. The court must then arrive at a judgment as to the relationship of that operation to the core federal undertaking, the necessary relationship being variously characterized as "vital”, “essential” or "integral”. 72

In upholding the trial judge's decision to dismiss the provincial charges for lack of jurisdiction, the Court of Appeal looked at the business of LeBlanc \& RoyleTelcom:

\begin{abstract}
While the trial judge did not state in his reasons what the "core federal undertaking” was, it is clear from those reasons that he was referring to that group of enterprises which are substantial customers of LeBlanc and which are engaged in interprovincial communication. They included Baton Broadcasting Inc., Bell Cellular, Cantel, B.C. Telephone, B.C. Cellular, Unitel Communications the successor to C.N.C.P. Telecommunications), the Canadian Broadcasting Corporation and the Canadian Armed Forces. Most, if not all of these, are federally regulated. Witnesses were called from each of the above. They testified as to the services provided by LeBlanc and the extent to which those services were integrated with the operations of the various customers. ${ }^{73}$
\end{abstract}

It was argued by the Crown that the business of LeBlanc \& RoyleTelcom was in the nature of construction, maintenance, and repairs (all provincially-regulated) and not operations related to the operations of its customers, the majority of which were shown to be federally regulated.

The Court found that LeBlanc's customers were federally-regulated and that LeBlanc's crew worked almost entirely on telecommunication towers. It was also determined that the work that the crews performed was an integral and vital part of the operations of LeBlanc's customers. On this basis, the Ontario Court of Appeal dismissed the provincial charge against LeBlanc for lack of jurisdiction.

71

Northern Telecom Limited v Communications Workers of Canada, [1980] 1 SCR 115 [Northern Telecom No 1].

$72 \quad$ Ibid at 132

73 LeBlanc, supra note 69 at 740. 


\section{DECLARATORY RELIEF AS A SOLUTION to a Constitutional Problem}

The authors of the Annotated Canada Labour Code ${ }^{74}$ state that both provincial and federal health and safety statutory provisions can co-exist on the same work site ${ }^{75}$ and reference the Northwest Territories \& Nunavut (Workers Compensation Board) v. Canada (A.G.) as a case in point. ${ }^{76}$

The Northwest Territories case involved a mine reclamation project on federally owned lands in the Northwest Territories. The territorial authorities applied to the Court for a declaration that the territorial mine safety legislation would not apply to the project. They made the argument that having two regimes apply to one project would create an "administrative nightmare."77 The Court agreed with the territorial authorities that one legislative regime would alleviate an otherwise real potential for confusion. Accordingly, the Court made a declaration that the CLC applied to the project and all parties working on it and that the territorial legislation did not apply at all. ${ }^{78}$

Despite the good intentions of the parties and the Court in the Northwest Territories case, it is doubtful that, where both provincial and federal laws apply, a court can make a declaration that one legal regime applies to make the administration of safety in order to be more successful. Unfortunately, a court cannot trump the Constitution Act, 1867 with common sense.

The confusion that can ensue from the uncertainty created by constitutional conundrums was addressed in the Bell Canada 1988 case, where the Court stated:

[I]n the case of occupational health and safety, such a twofold jurisdiction is likely to promote the proliferation of preventative measures and controls in which the contradictions or lack of coordination may well threaten the very occupational health and safety which are sought to be protected. ${ }^{79}$

There has been no resolution to the conflict between the application of federal and provincial occupational health and safety legislation pertaining to a single site.

Ronald M Snyder, The 2011 Annotated Canada Labour Code (Toronto: Carswell, 2010).

Ibid at 749 .

2007 NWTSC 109, 289 DLR (4th) 137 [Northwest Territories].

Ibid at para 4.

Ibid at paras 55-56.

Bell Canada 1988, supra note 12 at 843; see also Norman A Keith, in Canadian Health and Safety Law (Aurora: Canada Law Book, 2009) at 1:20, states that much of the uncertainty regarding the differences between provincial and federal jurisdiction was dealt with in the Bell Canada 1988 trilogy:

In these cases, the Supreme Court of Canada addressed the question of whether or not occupational

health and safety was sufficiently connected to the operation and management of a federally regulated enterprise, such that occupational health and safety issues also fell within the federal authority.

It is reasonably settled law that the provinces and territories can only properly regulate the safety and health in workplaces that fall within provincial jurisdiction. Provincial health and safety legislation does not apply to federal works or undertakings. Similarly federal health and safety legislation does not apply to provincial works or undertakings. However, the difficulty arises in the characterization and classification of the workplace, the nature of the employer and the nature of the work itself. The most complete legal analysis of the division of powers regarding occupational health and safety powers was found in the trilogy of cases decided by the Supreme Court of Canada. 


\section{WhiCh LEgISLATIVE REgIME APPLIES?}

The process for determining which legislative regime applies, or regimes apply, is as follows:

(1) Determine whether the owner is federally or provincially regulated;

(2) Determine if the owner's project is regulated differently than the owner's main business;

(3) If the project is provincially regulated and performed by:

(a) a provincially-regulated owner, the Alberta OH\&S Legislation applies to the owner and:

(i) the Alberta OH\&S Legislation applies to provincially-regulated contractors; and

(ii) the CLC applies to federally-regulated contractors;

(b) a federally-regulated owner, the CLC applies to the owner and:

(i) the CLC applies to federally-regulated contractors; and

(ii) the Alberta $\mathrm{OH \& S}$ Legislation applies to provincially-regulated contactors;

(4) If the project is federally regulated and performed by:

(a) a federally-regulated owner, the CLC applies to the owner and:

(i) the CLC applies to federally-regulated contractors; and

(ii) the Alberta OH\&S Legislation applies to provincially-regulated contactors;

(b) a provincially-regulated owner (that is, an owner that does not carry on a federal work or undertaking, but has an ancillary project that is federally regulated, for instance an interprovincial electrical connection or pipeline), the Alberta OH\&S Legislation applies to the owner and

(i) the Alberta $O H \& S$ Legislation applies to provincially-regulated contractors; and

(ii) the CLC applies to any federally-regulated contractors. 
It is noteworthy, however, that the provisions of the Criminal Code $e^{80}$ that apply to safety, known as "Bill C-45" or the Westray Amendments, ${ }^{81}$ apply to all projects, regardless of the jurisdictional issues raised by the Alberta OH\&S Legislation and the CLC.

\section{WHERE REGIMES COLLIDE}

How do businesses operate where these jurisdictional conflicts exist? We have analyzed this by using an example of a federally-regulated pipeline company, which we refer to as "Pipeco."

As a federally-regulated pipeline company, it is clear that Pipeco is under the jurisdiction of the $C L C$, in relation to occupational health and safety but, immediately, another nuance exists. Human Resources Development Canada (HRDC) and the NEB abide by a Memorandum of Understanding, which states:

\footnotetext{
The purpose of this memorandum of understanding (MOU) is to establish a joint administrative arrangement between Human Resources Development Canada — Labour Branch (HRDC-Labour) and National Energy Board (NEB) for the application and enforcement of the Canada Labour Code, Part II (the Code) in the federal oil and gas sector. ${ }^{82}$
}

In the MOU, the HRDC and the NEB commit to work together to "achieve the purpose of the Code," which is therein stated to "prevent accidents and injury to health arising out of, linked with or occurring in the course of employment." ${ }^{\text {"3 }}$ Also pursuant to this $M O U$, NEB employees are trained and appointed as HRDC safety officers. The result is that within the federal realm of occupational health and safety there are two categories of safety officers:

- $\quad$ NEB safety officers who carry out HRDC occupational and safety inspections and other duties at pipeline field sites; and

- $\quad$ HRDC staff safety officers who retain responsibility for health and safety issues and incidents at Pipeco’s head office.

For Pipeco, with or without the $M O U$ in place, in addition to the provisions of the $C L C$, the provisions of the National Energy Board Act ${ }^{84}$ and regulations ${ }^{85}$ also come into play. Pursuant to section 48 of the NEB Act, the NEB may order a company to take measures that

Bill C-45, An Act to amend the Criminal Code (criminal liability of organizations), 2nd Sess, 37th Parl, 2002, cl 3 (assented to 7 November 2003), SC 2003, c 21. The most significant of the Westray Amendments was the addition of section 217.1 to the Criminal Code, which states, "Everyone who undertakes, or has the authority, to direct how another person does work or performs a task is under a legal duty to take reasonable steps to prevent bodily harm to that person, or any other person, arising from that work or task.”

82 Memorandum of Understanding between Human Resources Development Canada and National Energy Board Respecting the Application and Enforcement of Canada Labour Code, Part II in the Federal Oil and Gas Sector (Ottawa: National Energy Board Acts and Regulations, 2000) at 1, online: <http://www. neb-one.gc.ca/clf-nsi/rpblctn/ctsndrgltn/mmrndmndrstndng/hmnrsrcdvlpmntcnd2000-eng.pdf $>$ [MOU]. Ibid.

RSC 1985, c N-7 [NEB Act].

National Energy Board Onshore Pipeline Regulations, 1999 SOR/99-294 [Onshore Pipeline Regulations]. 
the Board considers necessary "for the safety and security of a pipeline." ${ }^{\text {" }}$ For example, the Onshore Pipeline Regulations are the regulations pursuant to the NEB Act which apply with respect to the design, construction, operation, and abandonment of pipelines. ${ }^{87}$

Pursuant to the Onshore Pipeline Regulations, the NEB has a broad range of powers, including requirements to develop a "Safety Program," which provides that "[a] company shall develop, implement and maintain a safety management program that anticipates, prevents, manages and mitigates potentially dangerous conditions and exposure to those conditions during all activities relating to construction, operation, maintenance, and emergency activities." ${ }^{88}$

Section 49 of the NEB Act provides for the appointment of inspection officers and sets forth their duties in ensuring the safety and security of pipelines, the company's employees, and the public. ${ }^{89}$ The result is that NEB staff may be both inspection officers pursuant to the $N E B$ Act and safety officers pursuant to the $C L C$.

In summary, even before Pipeco encounters any potential conflict between provincial health and safety laws and federal health and safety laws under the $C L C$, Pipeco must ensure compliance with all of its health and safety obligations under federal laws.

\section{A. Pipeco Construction}

It is in the construction area where Pipeco fully encounters the collision between provincial and federal health and safety laws.

Interestingly, section 123(1) of the $C L C$ states that, "this Part applies to and in respect of employment (a) on or in connection with the operation of any federal work, undertaking or business." ${ }^{90}$ There is no reference to construction in this section. Nevertheless, the statement in Canadian Employment Law that "[g]enerally, safety in construction is governed by provincial regulation," ${ }^{, 1}$ is an oversimplification. Pipeco, as a federally-regulated pipeline, its federally-regulated undertakings and employees never cease to be governed by the CLC. But the collision between the federal and provincial health and safety regimes occurs head on in the construction situation because construction contractors and their subcontractors are rarely federally regulated entities, and never cease to be governed by the provincial health and safety laws.

The Onshore Pipeline Regulations provides that during the construction of a pipeline, a company shall develop a construction safety manual which must be submitted to the Board. ${ }^{92}$ In a major construction project by Pipeco, pursuant to which it constructed a pipeline across British Columbia, Alberta, and Saskatchewan, Pipeco prepared a construction safety manual in accordance with the Onshore Pipeline Regulations. This manual prepared by Pipeco was

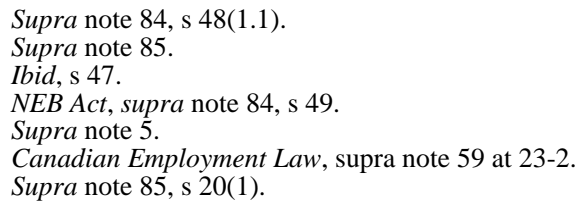


comprehensive, jurisdictionally neutral, required compliance by all contractors and their employees, and required that all contractors comply with all "applicable regulations.” The safety manual was very comprehensive, endeavoring to achieve the purpose of all potentially applicable regulations. For example, the manual provided for the designation of a prime contractor to accept responsibility for the coordination of construction health and safety regimes even though the $C L C$, and not all provincial jurisdictions have parallel legislation in this regard.

On this same Pipeco construction project, health and safety officials in two of the three provinces where this project was carried out declined to provide inspection, thereby presumably declining jurisdiction, but ironically one of the provinces not providing inspection did require from its head office that specific health and safety requirements be met for weld safety guards.

The practical answer to the question of whether federal or provincial health and safety laws apply in a specific circumstance is to look within the project as a whole to the specific party (owner, contractor, or employee) impacted to determine under whose jurisdiction that party is subject. In addition, in projects where such jurisdictional collision may occur, it is necessary to plan for health and safety based on the best rules and procedures to prevent incidents and injury.

\section{B. INCIDENT REPORTING}

One important aspect in this jurisdictional collision is incident reporting. Pipeco, as a federally-regulated entity, is required pursuant to Part XV of the Canada Regulations to immediately report, by telephone or telex, occupational health and safety incidents of various enunciated categories of seriousness set forth in the Canada Regulations. ${ }^{93}$ Pipeco also has reporting obligations pursuant to the Onshore Pipeline Regulations, but these reporting obligations are broader and not specific to occupational health and safety. ${ }^{94}$ In addition to the above referenced reporting requirements, there are also reporting requirements under the Canadian Transportation Accident Investigation and Safety Board Act ${ }^{95}$ and the Transportation Safety Board Regulations. ${ }^{96}$

There is no complete consistency between the definitions of a reportable incident or a serious injury under the CLC and the TSB Regulations, although both are federal jurisdictional regimes. For example, the TSB Regulations define a "serious injury" as an injury "likely to require admission to a hospital," ${ }^{97}$ whereas the Canada Regulations define a serious injury by enunciating various conditions, for example, fracture of a major bone, or third degree burns. ${ }^{98}$ In short, an incident under one regulation may not necessarily be reportable under another regulation.

Supra note 6.

Supra note 85, s 52.

SC 1989 , с 3.

SOR/92-446 [TSB Regulations].

Ibid, s 2.

Supra note 6. 
Practically, this reporting dilemma is resolved by the fact that the TSB Regulations tend to be broader and more encompassing, and by the fact that reporting only to the Transportation Safety Board is required, with transparency and cross communication between all three of these federal regulatory authorities being in place. Accordingly, a report to the Transportation Board is effectively a report to all three federal agencies. Pipeco would not, in normal circumstances, ever provide a report to provincial health and safety representatives.

\section{The Practical Solution}

In circumstances where the federal and provincial health and safety jurisdictions collide, such as in construction projects, there is no perfect answer to compliance. In practice, Pipeco has used the following guidelines to best ensure an effective health and safety program:

- $\quad$ cooperate and maintain an open communication with all regulators potentially having jurisdiction in the circumstance; and

- $\quad$ establish through project construction safety manuals and otherwise, standards which seek to achieve compliance with the stated purpose of all potentially governing regulations, and also to achieve the highest standards.

\section{Potential Resolutions}

It is clear that there is no definite answer to jurisdictional questions regarding occupational health and safety. However, there are some potential resolutions to this difficult conundrum:

(1) Parliament could legislate that provincial occupational health and safety laws will apply over all types of projects. An example of legislation where Parliament decreed that provincial laws were to apply in the face of federal legislation can be found at section 88 of the Indian Act, first enacted in 1951, as follows:

\footnotetext{
Subject to the terms of any treaty and any other Act of Parliament, all laws of general application from time to time in force in any province are applicable to and in respect of Indians in the province, except to the extent that those laws are inconsistent with this Act or the First Nations Fiscal Management Act, or with any order, rule, regulation or law of a band made under those Acts, and except to the extent that those provincial laws make provision for any matter for which provision is made by or under those Acts. ${ }^{99}$
}

If Parliament elected to make a similar law with respect to occupational health and safety, so that provincial occupational health and safety laws would apply except to the extent that those provincial laws directly conflict with federal legislation (other than specific federal occupational health and safety legislation), the grey area that currently exists with respect to jurisdictional issues would become more black and white. 
(2) Owners could apply to the court for a declaration that one particular occupational health and safety regime applies as was done in the Northwest Territories case. ${ }^{100}$ Although this solution has practical appeal, there are some pitfalls.

First, this solution may have succeeded because the Northwest Territories is not a province and different constitutional principles apply to territorial law than to the provinces. ${ }^{101}$ The conclusion reached in the Northwest Territories decision would not necessarily apply in Alberta.

Second, under Alberta law, a corporation would find it difficult to acquire standing to have the matter heard before a court, especially for the purposes of obtaining a declaration on the application of health and safety laws. Typically, Alberta courts do not interfere in the conduct of parties unless there is an underlying dispute which initiates the litigation process. Under section 26 of the Alberta Judicature Act, the "Lieutenant Governor in Council may refer to the Court of Appeal for hearing or consideration any matter the Lieutenant Governor in Council thinks fit to refer."102 The Alberta government could theoretically refer a matter to court to acquire a declaration as to what occupational health and safety laws apply to a given project at the outset of the project. However, on a one-off basis, this solution would not be practical or likely to occur.

(3) The parties themselves could come to an understanding regarding the application of occupational health and safety legislation on a project as was done in EllisDon. ${ }^{103}$ In that case, at the outset of the project, the Greater Toronto Airport Authority and the Ontario Ministry of Labour came to a mutual agreement that Ontario occupational health and safety laws would apply. While this solution has merit, the Ontario Court of Appeal, in analyzing what jurisdiction would apply in that case, clearly demonstrated that it was not bound by the agreement between the parties.

While the Ontario Court of Appeal ultimately followed the agreement, the Court's decision was only reached after it had conducted a thorough analysis of the jurisdictional issues. Faced with a similar situation, a court could just as easily side against an agreement made between parties as to the jurisdiction of occupational health and safety law that would apply to a project. This could lead to serious consequences if the parties had not been complying with the jurisdiction ultimately found by the court.

(4) Finally, and currently the only clear option available, is to live with an uncertain system and understand the consequences of having both federal and provincial regulatory regimes apply to a single project. To best mitigate the risks associated with this reality, a company should follow the lead of Pipeco and attempt to comply with both regimes to the extent that compliance is required. 


\section{APpendix A}

\section{Is YOUR ENTITY FEDERALLY REgULATED?}

Federal jurisdiction to regulate employment over an entity can be granted:

(1) when the employment relates to a work, undertaking or business within the realm of federal jurisdiction; or

(2) where the employment is "integral" to a federal undertaking.

The work (a physical thing), undertaking (an arrangement under which physical things are used), or business itself must be an interprovincial work or undertaking. Examples would be interprovincial or international oil and gas pipelines and additions to existing pipeline systems, international and designated interprovincial power lines, and frontier lands and offshore areas not covered by provincial/federal management agreements.

Federal jurisdiction may also arise because the business is "integral" to a core federal work or undertaking.

\section{IS YOUR PROJECT OR DIVISION FEDERALly REgULATED?}

Even though a business entity may be federally regulated, a project that it undertakes may be provincially regulated. For example:

(1) Canadian Pacific, a federally-regulated entity, found that its Empress Hotel in Victoria was a provincial undertaking because it was not exclusive to railway passengers; and

(2) Canadian National, although federally regulated, had a gravel pit used exclusively to provide ballast for the railway. The gravel pit was found to be provincially regulated because it lacked an overall degree of functional integration and common management.

Even though a business entity may be provincially regulated, a division of that entity may be federally regulated. For example:

(1) For Northern Telecom, a provincially-regulated business, a division of its workforce dealing with the installation of products for Bell Canada, a federallyregulated entity, was found to also be federally regulated for the purposes of labour relations.

In the following cases the local projects were found to be federally regulated in the same manner as the entity itself:

(1) For Westcoast, a federally-regulated entity, which built local expansions, the local works were federally regulated. 
(2) For Dome Petroleum, a federally-regulated entity, its underground storage tanks were considered integral and essential and were federally regulated.

\section{Does the Regulation of the Project \\ CHANGE THE REgUlATION OF THE ENTITY?}

(1) For both Montcalm and EllisDon, the federal nature of the airport projects they were working on did not change the fact that they were provincially regulated.

\section{DECISION TREE}

Assessing Which Occupational HeAlth ANd SAFETy Regime Applies

[figure to be inserted by Priority Printing -- please size to fit page margins] 